\begin{tabular}{|c|ccc|c|}
\hline & PORT SAID ENGINEERING RESEARCH JOURNAL \\
\hline
\end{tabular}

\title{
Thermal Performance Enhancement of a Practical Combined Gas-Steam Power Plant
}

\begin{abstract}
ALY KAMELABD El-SAMED

The research suggests some means to increase the very low overall efficiency and power output of existing combined plant. The effect of changing some operating parameters on the performance of the combined plant is investigated. Optimu m operating conditions are chosen to be run together lead to an increase of the net power output by $25.03 \%$ and the overall efficiency by $7.28 \%$. Good correlations are obtained correlating the net power output and overall efficiency of the combined plant with the operating parameters.
\end{abstract}

Keywords: Gas-Turbine, Steam-Turbine, Combined Plant, Operating Parameters.

\section{INTRODUCTION}

The gas and steam turbines are the greatest means to generate mechanical power. Both gas and steam turbines have been successfully working in large scale to generate the electricity. Combining the gas and steam cycles results in higher efficiency. The gas turbine using Brayton cycle and the steam power system using Rankine cycle are two such cycles that complement each other to form efficient combined cycle. The Brayton cycle has a high source temperature and rejects heat at a temperature such that it used as energy source for the Rankine cycle in a combined cycle. The heat recovery steam generator is one of the most important components of the combined cycle power plant. That significantly affects the efficiency. A typically high thermal efficiency of combined cycles ranged $50-60 \%$ is achieved $[1,2]$. The development in gas-turbine technology, as well as increases in steamturbine cycle temperature and pressure, heat recovery steam generator design enhancement is expected to achieve further combined plants efficiency improvement $[3,4]$. Also, the effect of various parameters like pinch point, steam pressure, steam temperature, and gas flow rate on the performance of the heat recovery steam generator are investigated [5]. Thermodynamic analysis of a combined cycle power plant with a supplementary firing system is investigated [6]. Alternative arrangements for improving the efficiency of the combined cycle is found that, reheat improves the cycle efficiency by 0.2 $0.4 \%$ compared to non-reheat cycles [7]. The dual pressure heat recovery steam generator have been widely used because they showed higher efficiency than single pressure systems and lower investment cost than triple pressure $[8,9]$. The maximum efficiency of the combined cycle is found to be at pressure ratio of 18 at the turbine inlet temperature $1400 \mathrm{~K}$ [10].

In the present work, parametric thermodynamic analys is of a practical combined gas-steam power plant is undertaken. The proposed power plant established

${ }^{T}$ Mechanical Power Department, Faculty of Engineering, Port-Said University and has been operated since 2010. Unfortunately, the maximum obtainable power is $570.669 \mathrm{MW}$ and the maximu calculated overall efficiency is found to be $38.59 \%$ which is very low compared to the practical values which ranged from $50 \%$ to $60 \%[1,2]$. Reevaluation of the effect of changing -in turn [11]- the operating parameters on the power plant performance is investigated in order to try to increase the power output and overall efficiency. The operating parameters include: the maximum gas temperature (which is a function of the fuel mass flow rate consumption), inlet air temperature, pressure ratio, and mass flow rate fraction of the low pressure steam. The performance of the plant is expressed in terms of: power out and efficiency of gas cycle, steam cycle and combined plant, specific power output, the dryness fraction of the exhaust steam and exhaust gas temperature. Also, the effect of adding supplementary firing unit on the combined plant performance is investigated.

For the combined plant each two gas turbine units supply their gases to operate one steam turbine unit as shown from the flow diagram of the plant in Fig. 1. The gas turbine unit is a simple cycle burns with natural gas. The steam cycle consists of two stages turbine (high and low pressures turbines), a de-aerator, and a dual pressure heat recovery steam generator.

The basic operating data of the gas-turbine, steamturbine, and combined plant (the case study) are presented and described in Table.1 as collected, derived and calculated for the power plant.

The effect of make-up steam and gland steam condenser is ignored. The specific heat capacity of the gas is calculated as a function of the gas temperature and mass fraction of the combustion products constituents consequently, the basic $\mathrm{Cp}_{\text {)g }}$ is found to be $1.05 \mathrm{KJ} / \mathrm{Kg}$. K. Applying the thermodynamics relations of the perfect gas and energy balance equations for each element of the combined power plant yields: the gas temperatures, steam enthalpies and extracted steam mass flow rate which be used to calculate the 
Table-1

\begin{tabular}{|c|c|}
\hline $\begin{array}{l}\text { Air mass flow rate for the two gas turbines = } \\
1572.6 \mathrm{~kg} / \mathrm{s}\end{array}$ & $\mathrm{T}_{\text {inlet airtemperature }}=22^{\circ} \mathrm{C}$ \\
\hline $\begin{array}{l}\text { Specific heat capacity of air } \mathrm{C}_{\mathrm{p}) \text { air }}=1.005 \\
\mathrm{~kJ} / \mathrm{kg} . \mathrm{K}\end{array}$ & Pressure ratio of the air compress or $=16.9$ \\
\hline$\gamma_{\text {air }}=1.4$ & Compressed air temperature $=414^{\circ} \mathrm{C}$ \\
\hline $\begin{array}{l}\text { Fuel mass flow rate for the two gas turbines = } \\
30 \mathrm{~kg} / \mathrm{s}\end{array}$ & Gas temperature inlet to gas-turbine $=1219^{\circ} \mathrm{C}$ \\
\hline Total gases flow rate $=1602.6 \mathrm{~kg} / \mathrm{s}$ & Exit gas temperature of gas turbine $=597^{\circ} \mathrm{C}$ \\
\hline Calorific value of natural gas $=49291 \mathrm{~kJ} / \mathrm{kg}$ & Exhaust gas temperature $=230^{\circ} \mathrm{C}$ \\
\hline Total steam mass flow rate $=210 \mathrm{~kg} / \mathrm{s}$ & High pressure live steam $=90$ bar \\
\hline$\left(\dot{m}_{\text {L.P.Steam }} / \dot{m}_{\text {Tot al .Steam }}\right) \%=30 \%$ & Low pressure live steam $=4.4$ bar \\
\hline$\eta_{\text {combustion chamber }}=\eta_{\text {combustion Supplementary }}=96.36 \%$ & Temperature of high pressure live steam $=508^{\circ} \mathrm{C}$ \\
\hline$\eta_{\text {heat recovery steam generator }}=89.33 \%$ & Temperature of low pressure live steam $=254^{\circ} \mathrm{C}$ \\
\hline$\eta_{\text {Mechanical }}$ ) pump $=97 \%$ & Exit te mperature of high pressure steam turbine $=216^{\circ} \mathrm{C}$ \\
\hline$\eta_{\text {Mechanical ) Gas Turbine }}=98 \%$ & De-aerator pressure $=1.69 \mathrm{bar}$ \\
\hline$\eta_{\text {Mechanical }}$ )Steam Turbine $=98 \%$ & Inlet temperature to low pressure steam turbine after mixing point $=22 \mathrm{PC}$ \\
\hline$\eta_{\text {Steam } \text { )generator }}=99 \%$ & $\chi($ steam dryness fraction $)=0.93$ \\
\hline$\eta_{\text {GasTurbine } \text { )generator }}=98 \%$ & Pressure of steam condenser $=0.05$ bar \\
\hline$\eta_{\text {isentropic of compressor }}=92 \%$ & Effectiveness of the heat recovery steam generator $=0.68$ \\
\hline$\eta_{\text {isentropic of gas turbine }}=87 \%$ & Power output of the two gas turbines $=394.962 \mathrm{MW}$ \\
\hline$\eta_{\text {isentropic of high pressure steam turbine }}=74 \%$ & Power output of the two stages steam turbines $=175.707 \mathrm{MW}$ \\
\hline$\eta_{\text {isentropic of low pressure steam turbine }}=70 \%$ & Power output of the combined plant $=570.669 \mathrm{MW}$ \\
\hline
\end{tabular}

Power $_{\text {compressor }}=\dot{m}_{a} C p_{a}\left(T_{2}-T_{1}\right) \quad K W$

$\eta_{C C}=\frac{\dot{m}_{g} C p_{g} T_{3}-\dot{m}_{a} C p_{a} T_{2}}{\dot{m}_{\text {fuel }) c c} \times C . V .}$

Power $_{G T}=\dot{m}_{g} C p_{g}\left(T_{4}-T_{3}\right) \quad K W$

Power $_{G T \text { net }}=$ Power $_{G T}+$ Power $_{\text {Compressor }} \quad K W$

$\dot{Q} a d d=\dot{m}_{g} C p_{g} T_{3}-\dot{m}_{a} C p_{a} T_{2} \quad K W$

$\eta_{\text {thermal }) \mathrm{GT}}=\frac{\left.- \text { Power }_{G T}\right) \text { net }}{\text { Qadd }}$

Power $_{\text {output }) G T}=\left(\right.$ Power $_{G T}+$ Power $\left._{\text {Compressor }}\right) \eta_{\text {mec hGT }} \eta_{E G} \quad K W$

$\eta_{\text {steam generator }}=\frac{\dot{m}_{\text {steamHP }}\left(h_{6}-h_{14}\right)+\dot{m}_{\text {steamLP }}\left(h_{7}-h_{13}\right)}{\dot{m}_{g} C p_{g}\left(T_{4}-T_{5}\right)}$

...(8) 


$$
\begin{aligned}
& \text { Power }_{H P T}=\dot{m}_{\text {steamHP }}\left(h_{8}-h_{6}\right) \quad K W \\
& \text { Power }_{L P T}=\dot{m}_{\text {steamLP }}\left(h_{10}-h_{9}\right) \quad K W \\
& \text { Power }_{S T}=\text { Power }_{H P T}+\text { Power }_{L P T} \quad K W \\
& \text { Power }_{S T) n e t}=\left[\operatorname{Power}_{S T} \cdot \eta_{\text {mec } h S T}+\frac{\text { Power }_{S P}}{\eta_{\text {mec } h P}}\right] \quad K W \\
& \eta_{\text {thermal }) \mathrm{ST}}=\frac{- \text { Power }_{S T) \text { net }}}{\dot{m}_{\text {steamHP }}\left(h_{6}-h_{14}\right)+\dot{m}_{\text {steamLP }}\left(h_{7}-h_{13}\right)} \\
& \text { Power }_{\text {output ) } S T}= \\
& {\left[\operatorname{Power}_{S T} \cdot \eta_{\text {mec } h S T}+\frac{\text { Power } S P_{\text {mec } h P}}{\eta_{\text {me }}}\right] \cdot \eta_{E G}+\text { Power }_{\text {auxiliary }}} \\
& \text { Power }_{\text {output ) combined plant }}=\text { Power }_{\text {output }) G T}+\text { Power }_{\text {output }) S T} \quad K W \\
& \eta_{\text {overall ) combined plant }}=\frac{- \text { Power }_{\text {output }) \text { combined plant }}}{\text { fuel consumption rate } \times \text { calorific value }} \\
& \text { Extra heat added in supplementary firing system }=m_{\text {fuel extra }} \times C . V . \times \eta_{c s} \ldots . \\
& =m_{g) \text { total }} C p_{g}\left(T_{g}-T_{4}\right)
\end{aligned}
$$

Where,

$\mathrm{m}_{\text {gas }) \text { total }}=$ air flow rate + fuel rate in combustion chamber + extra fuel rate

$\dot{\mathrm{m}}=$ mass flow rate

$\mathrm{T}=$ te mperature

$\eta=$ efficiency

$\mathrm{h}=$ steam enthalpy

$\mathrm{Cp}=$ specific heat capacity

C.V. = calorific value of fuel (Natural Gas)

$\mathrm{Q}=$ heat flow rate

\section{subscripts}

\section{$\mathrm{a}=\mathrm{air}$}

$\mathrm{g}=$ gas

$\mathrm{cc}=$ combustion chamber

$\mathrm{HP}=$ High pressure

LP $=$ Low pressure

HPT $=$ High pressure turbine

LPT $=$ Low pressure turbine

cs $=$ combustion in supplementary

$\mathrm{EG}=$ electric generator

GT $=$ gas turbine

$\mathrm{ST}=$ steam turbine

$\mathrm{SP}=$ steam pumps

\section{RESULTS}

From the collected operating data of the practical combined plant, it is found that the produced net power output is $570.669 \mathrm{MW}$ and the calculated overall efficiency of the plant is $38.59 \%$ which unfortunately less than the expected range $50-60 \%[1,2]$. That may be due to not chosen the proper operating conditions. So the effect of changing the values of the basic operating condition which are: fuel mass flow rate consumption
$30 \mathrm{Kg} / \mathrm{s}$, pressure ratio of the air co mp res sor 16.9, inlet air temperature $22^{\circ} \mathrm{C}$ and mass flow rate fraction of the low pressure steam 0.3 on the performance of the combined plant are investigated in turn (i.e. changing one parameter and keeping the other three parameters constant).

\subsection{EFFECT OF CHANGING THE FUEL MASS FLOW RATE CONSUMPTION}

As the fuel mass flow rate consumption of the two gas turbines increases from $18.46 \mathrm{Kg} / \mathrm{s}$ to $33.66 \mathrm{Kg} / \mathrm{s}$, consequently the maximu $\mathrm{m}$ gas temperature inlet to the gas turbines increases significantly from $919^{\circ} \mathrm{C}$ to $1319^{\circ} \mathrm{C}$ respectively. That leads to a significantly increase of the gas turbine power output and a slight increase of the steam turbine power output. As a result, the summation of the gas and steam turbines power output increases from $336.9 \mathrm{MW}$ to $650.1 \mathrm{MW}$ as shown in Fig.2a. In other words, as the maximum gas temperature increases from $919^{\circ} \mathrm{C}$ to $1319^{\circ} \mathrm{C}$ the power output of the combined plant increases by $93 \%$. Consequently, the thermal efficiencies of the gas turbine and steam turbine increase gradually and the overall efficiency of the combined plant increases from $37 \%$ to $39.2 \%$ (i.e. increases by $6 \%$ ) as shown in Fig.2b. Also from Fig.2c, the dryness fraction of the exhaust steam is found to be increased from 0.86 to 0.95 and unfortunately the exhaust (chimney) gas temperature increases from $93.4^{\circ} \mathrm{C}$ (not recommended because it is less than $100^{\circ} \mathrm{C}$ ) to $278.4^{\circ} \mathrm{C}$ which leads to extra loss of heat due to a bad design of the heat recovery steam generator. Finally, the specific power output (=total power output/total fuel consumption) is 
found to be increased slightly from $18.3 \mathrm{MW} / \mathrm{Kg} / \mathrm{s}$ to 19.3 MW/Kg/s as shown in Fig.2d.

\subsection{EFFECT OF CHANGING THE INLET AIR TEMPERATURE}

As the inlet air temperature decreases from $40^{\circ} \mathrm{C}$ to $10^{\circ} \mathrm{C}$, the inlet gas temperature to the gas turbine decreases significantly from $1265^{\circ} \mathrm{C}$ to $1154^{\circ} \mathrm{C}$, but the power output of the gas turbine increases from 380.75 MW to $411.64 \mathrm{MW}$ due to the increase of the inlet air density. While, for the steam turbine the power output decreases from $180.089 \mathrm{MW}$ to $169.898 \mathrm{MW}$, that is due to the reduction of the gas temperature exits from the gas turbine and consequently to the reduction of heat transfer to the steam. Accordingly, the power output of the combined plant increases from 560.839 MW to $581.538 \mathrm{MW}$ as shown in Fig.3a (i.e. the net power increases by $3.69 \%$ ). Similarly, it is found that the steam turbine efficiency decreases but gas turbine efficiency increases slightly. Therefore, the overall combined plant efficiency increases slightly from $38 \%$ to $39.3 \%$ as shown from Fig. $3 b$ (i.e. the overall efficiency increases by $3.42 \%$ ). As a result, both of the exhaust gas temperature and exhaust steam dryness fraction decreases to be $200.93^{\circ} \mathrm{C}$ and 0.915 respectively as shown from Fig.3c. The specific power output of the combined plant increases gradually from $18.695 \mathrm{MW} / \mathrm{Kg} / \mathrm{s}$ to $19.108 \mathrm{MW} / \mathrm{Kg} / \mathrm{s}$ as the inlet air temperature decreases from $40^{\circ} \mathrm{C}$ to $3^{\circ} \mathrm{C}$, then it increases significantly up to $20.286 \mathrm{MW} / \mathrm{Kg} / \mathrm{s}$ as the inlet air temperature further decreases down to $-10^{\circ} \mathrm{C}$ as shown in Fig.3d. Absorption chillers could be used to reduce the inlet air temperature [12].

\subsection{EFFECT OF CHANGING THE COMPRESSOR PRESSURE RATIO}

As the pressure ratio of the air compressor increases from 8 to 20 (which within the practical range), the compressed air temperature increases and consequently that leads to an increase of the gas temperature inlet to the gas turbine from $1089^{\circ} \mathrm{C}$ to $1251^{\circ} \mathrm{C}$ after the combustion process. So, the power output of the gas turbine increases but it decreases for the steam turbine. The summation of the two powers leads to an increase of the combined plant from 513.4 MW to $577 \mathrm{MW}$ (i.e. an increase by $12.4 \%$ ) as shown in Fig.4a. The efficiency of the gas turbine cycle increases significantly while the efficiency of the steam turbine cycle decreases slightly. So, the overall efficiency of the combined plant increases from $35 \%$ to $39 \%$ (i.e. increases by $11.42 \%$ ) as shown in Fig.3b. Both of the exhaust gas temperature and steam dryness fraction decreases and exits at $224.6^{\circ} \mathrm{C}$ and 0.925 respectively as shown in Fig.3c. The specific power output is found to be increases significantly from $17.1 \mathrm{MW} / \mathrm{Kg} / \mathrm{s}$ to 19.2 MW/Kg/s as shown in Fig.3d. So, re-design of the air compress or may be required.

\subsection{EFFECT OF CHANGING THE MASS FLOW RATE FRACTION OF THE LOW PRESSURE STEAM}

The dual pressure heat recovery steam generator (high and low pressures steam) is applied for the combined plant case study. As the mass flow rate fraction of the low pressure steam (= mass flow rate of steam at low pressure/total mass flow rate of steam) decreases from 0.95 to 0.05 , that will not affect the gas turbine performance but increase the power output and efficiency of the steam turbine cycle significantly as shown in Fig.4a. Also, the overall efficiency of the combined plant increases from $35.377 \%$ to $39.4 \%$ (i.e. increases by $11.37 \%$ ) and the specific power output increases from $17.438 \mathrm{MW} / \mathrm{Kg} / \mathrm{s}$ to $19.42 \mathrm{MW} / \mathrm{Kg} / \mathrm{s}$ as shown in Fig.4d accompanied with a reduction of steam dryness fraction down to low value of 0.885 . So, re-design for the dual steam generator and turbines may be required.

\subsection{EFFECT OF ADDING SUPPLEMENTARY FIRING SYSTEM}

For the combined plant case study the fuel consumption flow rate in the combustion chambers of the gas turbines is $30 \mathrm{Kg} / \mathrm{s}$. Extra amount of the fuel $3.66 \mathrm{Kg} / \mathrm{s}$ is added to the combustion chambers of the gas turbines and other time to the heat recovery steam generator such that the total fuel consumption flow rate for both cases becomes the same of $33.66 \mathrm{Kg} / \mathrm{s}$ (at which the thermal performance is high). It can be noticed that, as the extra fuel is burnet in the supplementary firing system the power output of the steam cycle increases slightly while the power of the gas turbine remains as it is and the overall power output of the plant increases from 570.669 MW to $587.962 \mathrm{MW}$. While burning the extra fuel in the combustion chambers of the gas turbines instead of supplementary system leads to a significant increase of the power output of gas turbine cycles as well as of the combined plant from $394.962 \mathrm{MW}$ and $570.669 \mathrm{MW}$ to be $465.288 \mathrm{MW}$ and $650.113 \mathrm{MW}$ respectively. Adding extra fuel in the combustion chambers produces overall efficiency of $39.18 \%$ greater than that in supplementary system which produces overall efficiency of $35.4 \%$. So, it is recommended to burn the extra fuel in the combustion chambers of the gas turbines rather than in the supplementary system if higher power, higher overall efficiency and lower exhaust gas temperature are required as shown from Fig.5. But, materials of ducts and turbines blades with higher specifications in order to withstand the higher thermal stress will be needed and will be much costly.

\subsection{CORRELATIONS}

Corre lations have been done in order to correlate the net power output and overall efficiency of the combined plant with the investigated operating parameters which are: the total fuel mass flow rate, inlet air temperature, pressure ratio, and mass flow rate fraction of the low pressure steam using statistical package social sciences (S.P.S.S.) software in order to analyze the data using multiple liner regression models. The net power output of the combined plant correlation is expressed as: 


$$
\begin{aligned}
\text { Power }_{\text {combined }} & =-3.712+20.37 \dot{m}_{\text {fuel }}+5.678 R_{P} \\
& -0.417 T_{\text {air }}-65.072 \frac{\dot{m}_{\text {steam } L P}}{\dot{m}_{\text {total Steam }}} \\
\text { Error rate equation }= & 3.49925 \%
\end{aligned}
$$

$$
\begin{aligned}
& \text { Also, the overall efficiency of the combined plant } \\
& \text { correlation is expressed as: } \\
& \qquad \begin{aligned}
\boldsymbol{\eta}_{\text {Combined }} & =37.569+0.133 \dot{m}_{\text {fuel }}+0.364 R_{P} \\
& -0.027 T_{\text {air }}-4.393 \frac{\dot{m}_{\text {steam LP }}}{\dot{m}_{\text {total Steam }}}
\end{aligned} \\
& \text { Error rate equation }=0.19624 \%
\end{aligned}
$$

Where:

Power $)_{\text {Combined }}=$

Net output power of the combined plant MW

$\eta_{\text {Combined }}=$

Overall efficiency of the combined plant \%

$\dot{m}_{\text {fuel }}=$ Fuel mass flow rate consumption in

combustion chamber $\mathrm{kg} / \mathrm{s}$

$R_{P}=$ Compressor pressure ratio $-T_{\text {air }}$ = Inlet air temperature $K$

$\frac{\dot{m}_{\text {steam } L P} L}{\dot{m}_{\text {total }} \text { Steam }}=$

mass flow rate fraction of low pressure steam -

$=\frac{\text { mass flow rate of steam at low pressure }}{\text { total mass flow rate of steam }}$

\section{CONCLUSIONS}

1- The study is an attempt to increase the net power output and overall efficiency of the combined plant by increasing the maximum gas temperature and pressure ratio but reducing the inlet air temperature and mass flow rate fraction of the low pressure steam. The previous parameters are correlated in good obtainable correlations as follows:

$$
\begin{aligned}
& \text { Power } \boldsymbol{C}_{\text {Combined }} \\
& =-3.712+20.37 \dot{m}_{\text {fuel }} \\
& +5.678 R_{P}-0.417 T_{\text {air }} \\
& -65.072 \frac{\dot{m}_{\text {steam } L P}}{\dot{m}_{\text {total Steam }}} \\
& \eta_{\text {Combined }}=37.569+0.133 \dot{m}_{\text {fuel }}+ \\
& 0.364 R_{P}-0.027 T_{\text {air }}- \\
& 4.393 \frac{\dot{m}_{\text {steam } L P}}{\dot{m}_{\text {total Steam }}}
\end{aligned}
$$

2- Increasing the basic fuel consumption rate from $30 \mathrm{Kg} / \mathrm{s}$ to $33.66 \mathrm{Kg} / \mathrm{s}$ (i.e. increasing the maximum inlet gas temperature from $1219^{\circ} \mathrm{C}$ to $1319^{\circ} \mathrm{C}$ ) this will lead to an increase of the power output and overall efficiency by $13.92 \%$ and $1.53 \%$ respectively.

3- Decreasing the basic inlet air temperature fro $m 40^{\circ} \mathrm{C}$ to $-10^{\circ} \mathrm{C}$ leads to an increase of the power output and overall efficiency by $3.69 \%$ and $3.42 \%$ respectively.

4- Increasing the basic air compressor pressure ratio from 16.9 to 20 leads to an increase of the power output and overall efficiency by $1.11 \%$ and $1.06 \%$ respectively.

5- Decreasing the basic mass flow rate fraction of the low pressure steam from 0.3 to 0.05 leads to an increase of the power output and overall efficiency by $2.1 \%$ and $2.1 \%$ respectively.

6- The optimu $m$ values fro $m$ the above operating parameters are chosen to operate together. The corresponding obtainable power output is found to be increased up to $713.5 \mathrm{MW}$ and the overall efficiency increased up to $41.4 \%$. In other words the net power output increases by $25.03 \%$ and the overall efficiency increases by $7.28 \%$. To achieve that, re-design of some elements of the combined plant may be required.

7- Burning extra fuel in the basic combustion chamber produces significantly higher power output and higher overall efficiency rather than burning the extra fuel in the supplementary firing system. But costly materials for ducts and turbines blades with higher technical specification must be considered.

\section{REFERENCES}

1. Darwish, M.A., "The cogeneration power-desalting plant with combined cycle: a computer program", Desaltination, 2000, Vol. 127, pp:27-45.

2. Mitre, J.F., Lacerda, A.I., and Lacerda, R.F., "Modeling and simulation of thermoelectric plant of combined cycles and its environmental impact" Thermal Engineering, 2005, Vol.4, No.1, pp:83-88.

3. Kaushika, S.C., Reddya, V.S., and Tyagi, S.K., "Energy and exergy analyses of thermal power plants: A review" Renewable and Sustainable Energy Reviews, 2011, Vol.15, pp:1857-1872.

4. Chih, W., "thermodynamics and heat powered cycles: a cognitive engineering approach," Nova Science Publishers, Inc. New York 2007.

5. Ravi Kumar, N., Rama Krishna, K., Sita Rama Raju, A.V., "Thermodynamic analysis of heat recovery steam generator in combined cycle power plant," Thermal Science, II, 2007, 4, pp:143-156.

6. Ahamadi, P., Dincer, I., "Thermodynamic analysis and thermoeconomic optimization of a dual pressure combined cycle power plant with a supplementary firing unit," Energy Conversion and Management, 52, 2011, 5, pp:2296-2308.

7. Bolland, O., "A comparative evaluation of advance combined cycle alternatives, Journal of Engineering for Gas Turb ine and Power, 1991, 113, pp:190-197.

8. P.R. Kumar, V.D. Raju " Off design performance analysis triple pressure of heat recovery steam generator" Int. J. of Research and Technology, 2012, Vol.1, is 5.

9. Ravi Kumar, N., "Thermodynamic analysis of heat recovery steam generator in combined cycle power plant" Thermal Science, 2007, Vol.11, No.4, pp:143-156.

10. Sanjay, Singh O., Prasad B.N., "Influence of different means of turbine blade cooling on the thermodynamic performance of combined cycle" Appl. Therm. Eng., 2008, Vol.28, pp:2315-2326.

11. Muammer Alus and Milan V. Petrovic "Optimization of the triple pressure comb ined cycle 
power plant" Thermal Science, 2012, Vol.16, No.3, pp:901-914.

12.S.Boonnasa, P.Namprakai, T.Muangnapoh "Performance improvement of the combined cycle power plant by intake air cooling using an absorption chiller" Energy, 2006, Vol.31, pp:2036-2046.

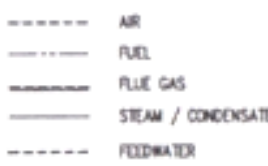

bert sua coerdion

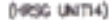
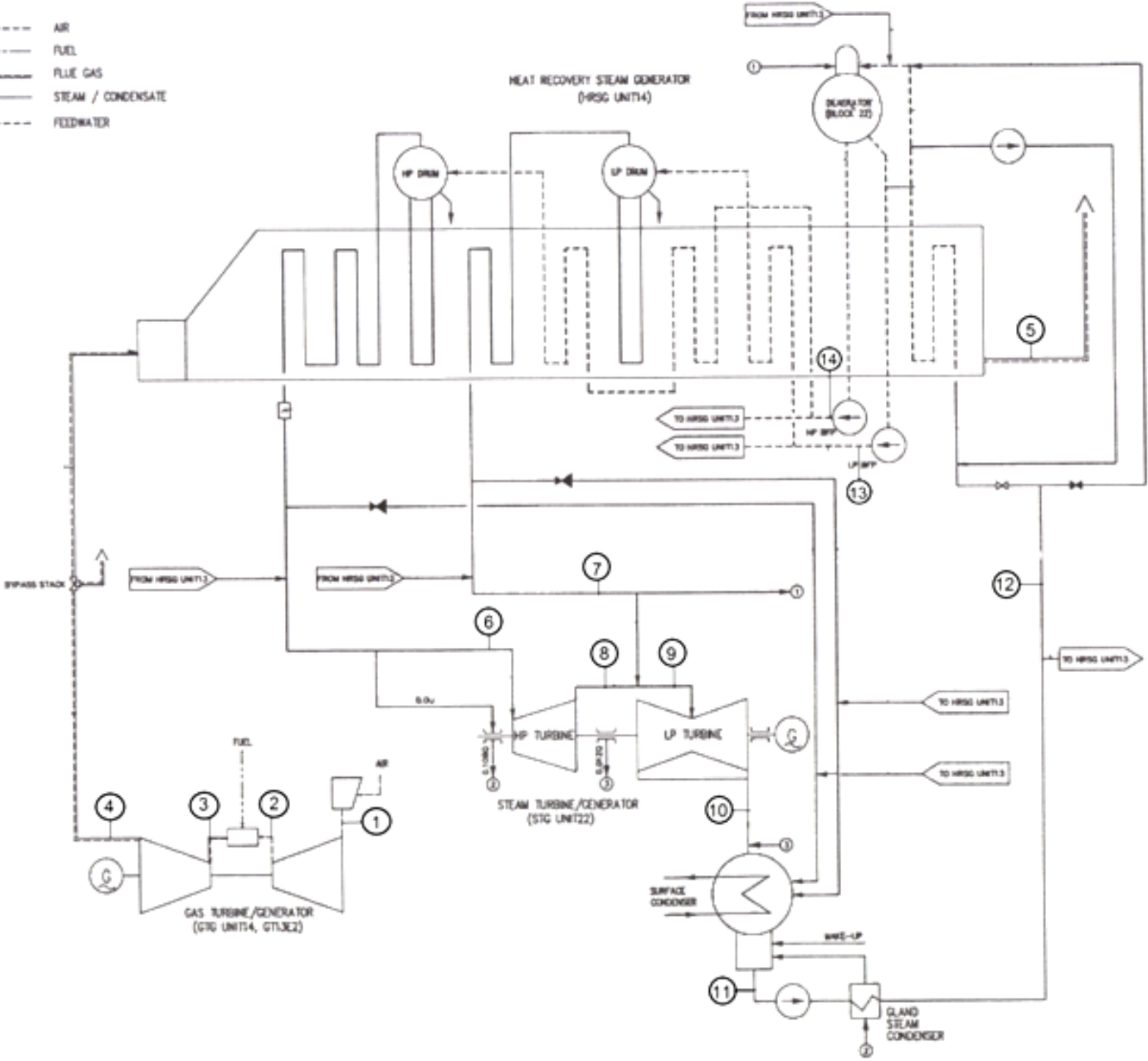

Fig.1 The Flow Diagram of The Combined Power Plant
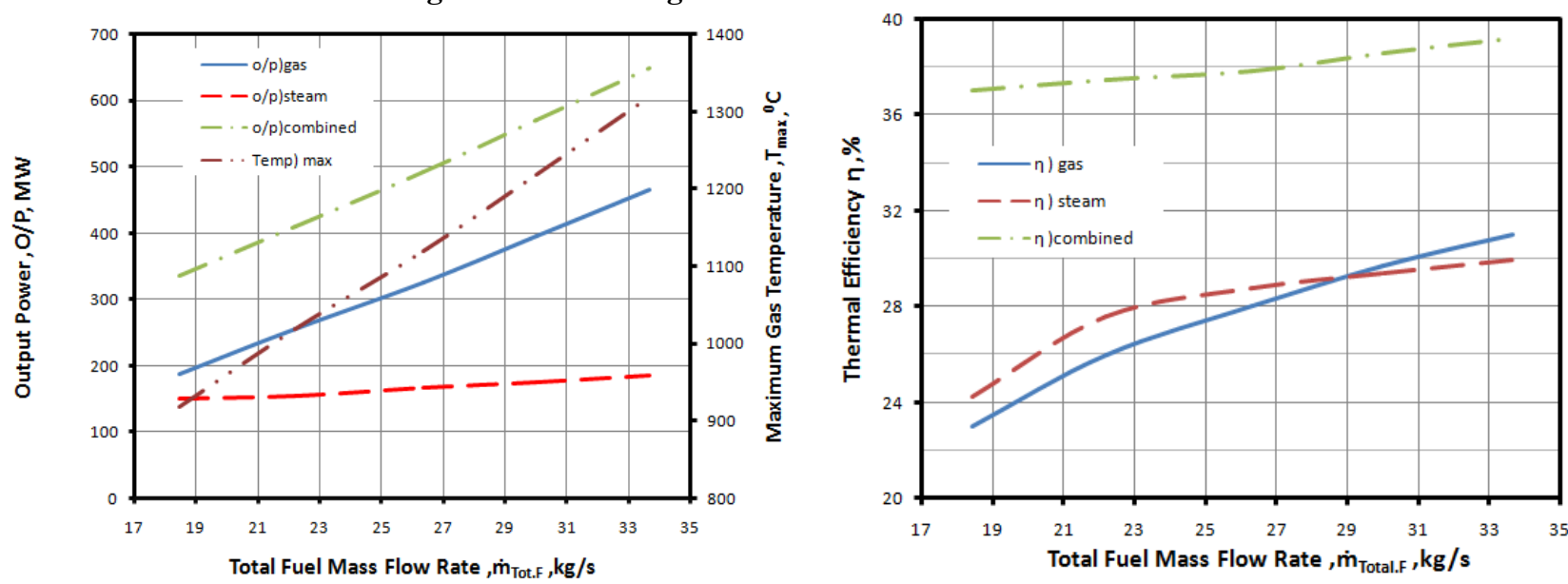
(a)

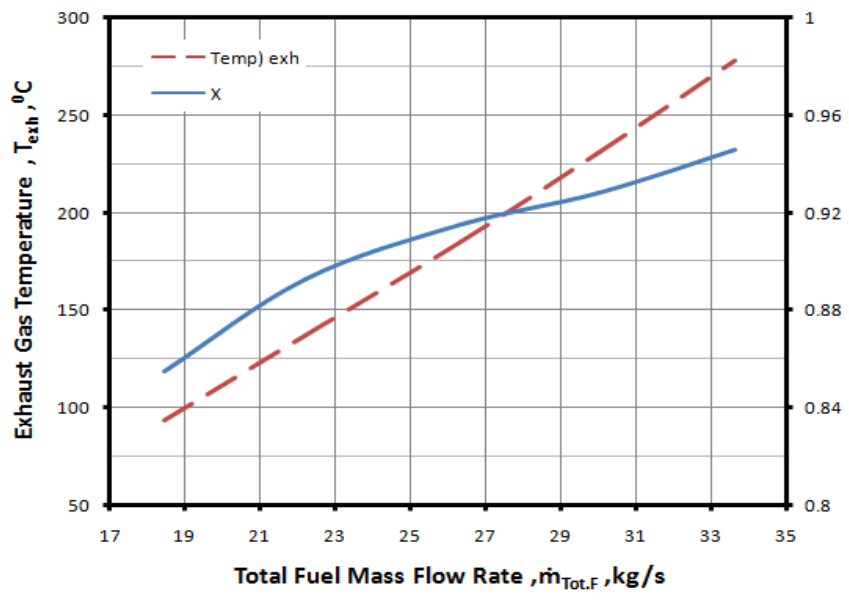

(C) (b)

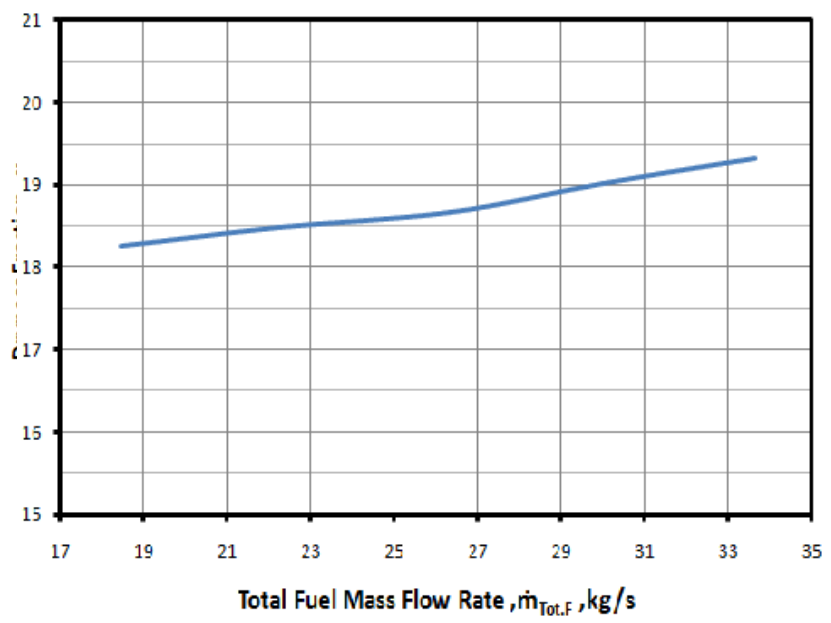

(d)

Fig.2 Effect of changing the fuel mass flow rate consumption on the performance of the combined plant. $\left(R_{\mathbf{P}}=16.9, \mathbf{T}_{\mathrm{air}}=\mathbf{2 9 3 K}, \frac{\dot{m}_{\text {L.P.Steam }}}{\dot{m}_{\text {Total Steam }}}=\mathbf{3 0 \%}\right)$

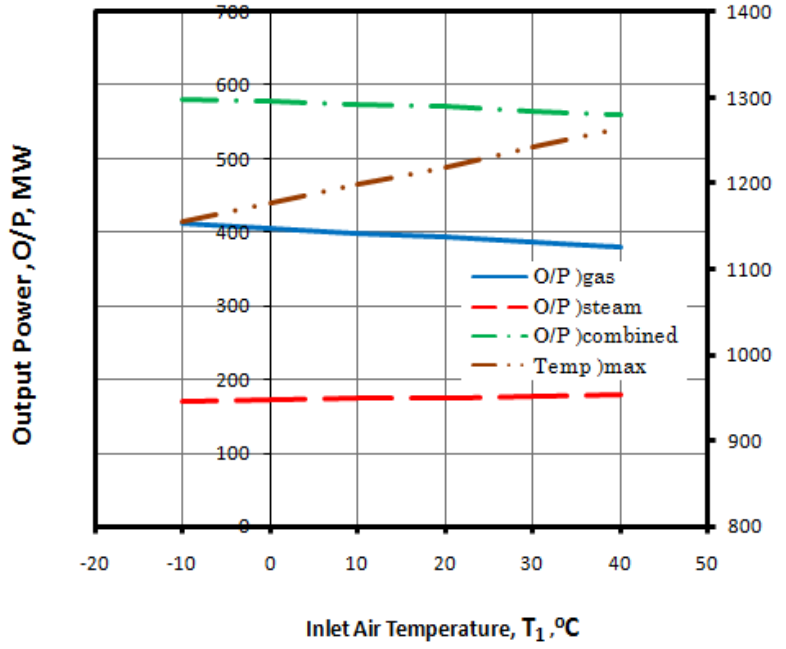

(a)

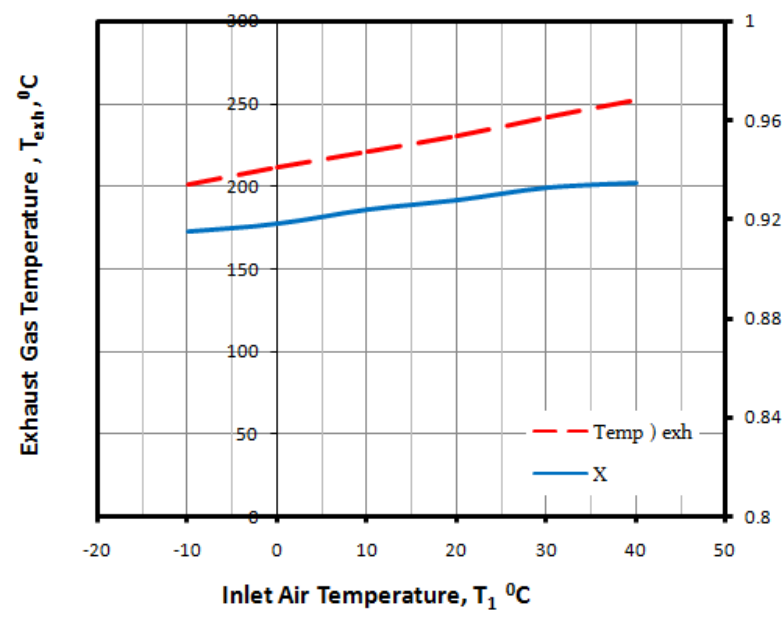

(C)

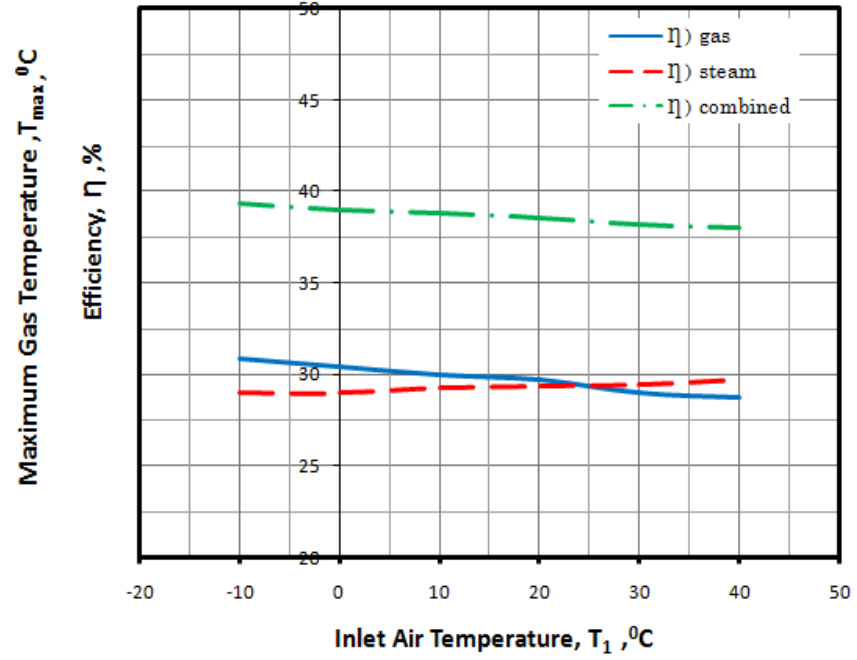

(b)

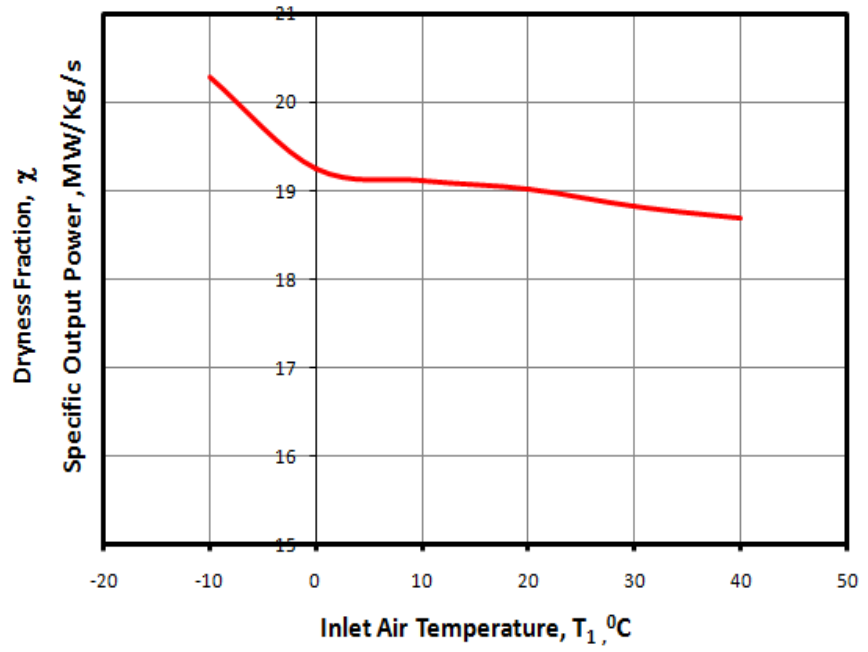

(d) 
Fig.3 Effect of changing the inlet air temperature on the performance of the combined plant.

$$
\left(\dot{m}_{\text {fuel }}=30 \mathrm{Kg} / \mathrm{s}, \mathbf{R}_{\mathrm{P}}=16.9, \frac{\dot{m}_{\text {L.P Steam }}}{\dot{m}_{\text {Total Steam }}}=30 \%\right)
$$

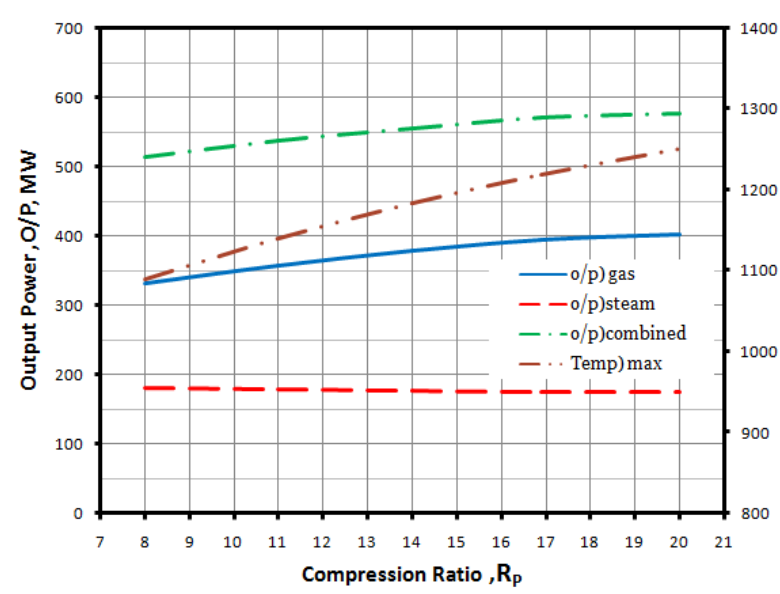

(a)

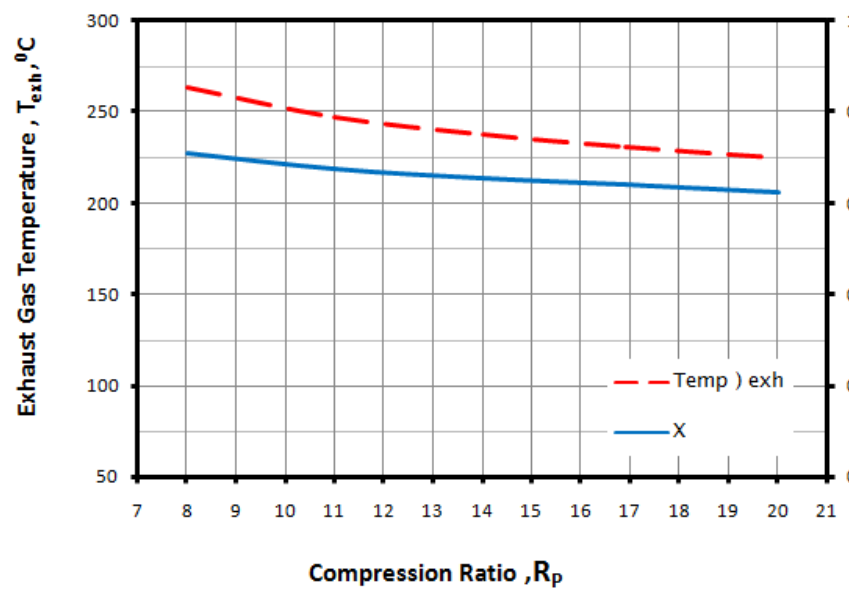

(c)

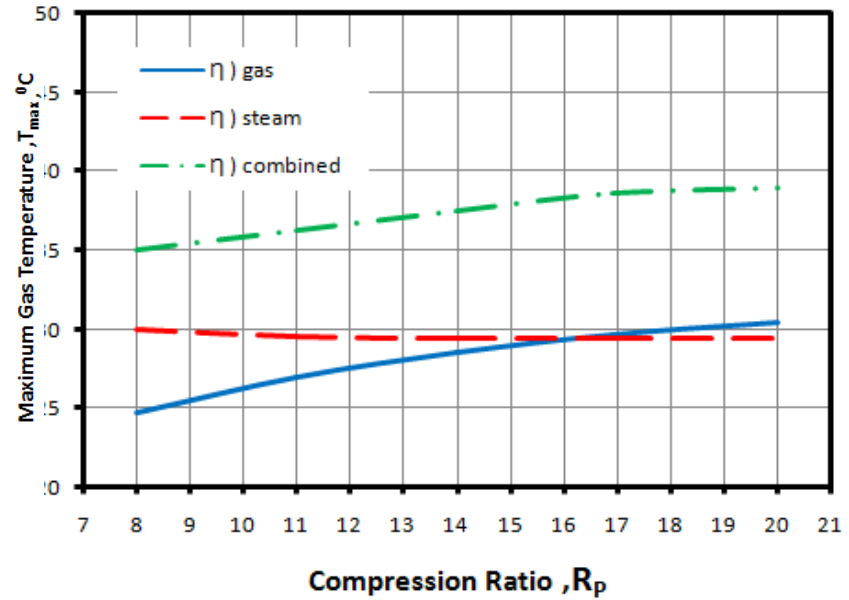

(b)

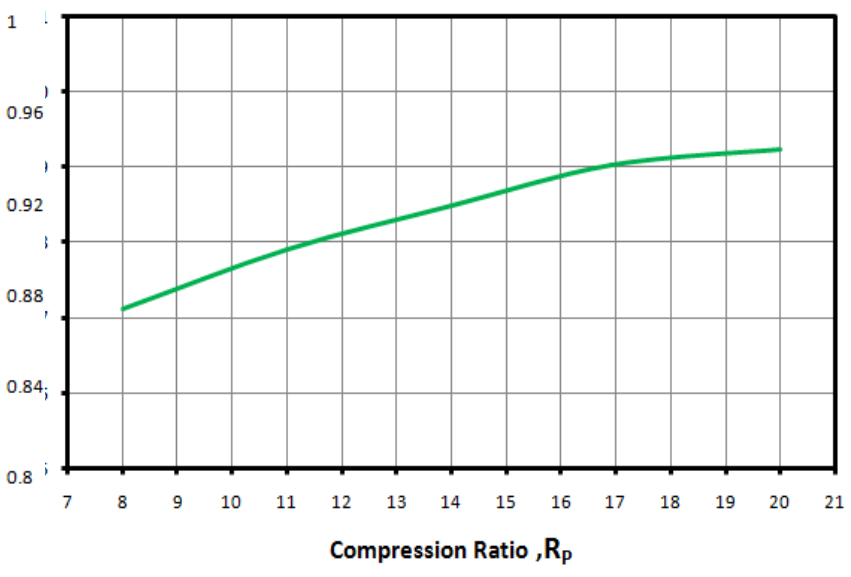

(d)

Fig.4 Effect of changing the compressor pressure ratio on the perfor mance of the combined plant.

$$
\left(\dot{m}_{\text {fuel }}=30 \mathrm{Kg} / \mathrm{s}, \mathbf{T}_{\text {air }}=293 \mathrm{~K}, \frac{\dot{m}_{\text {L.P.Steam }}}{\dot{m}_{\text {Total Steam }}}=30 \%\right)
$$

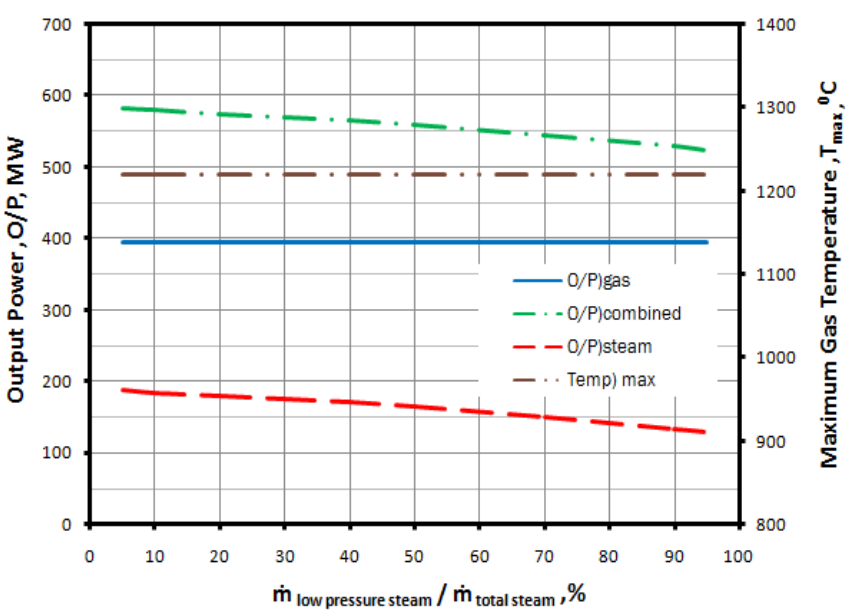

(a)

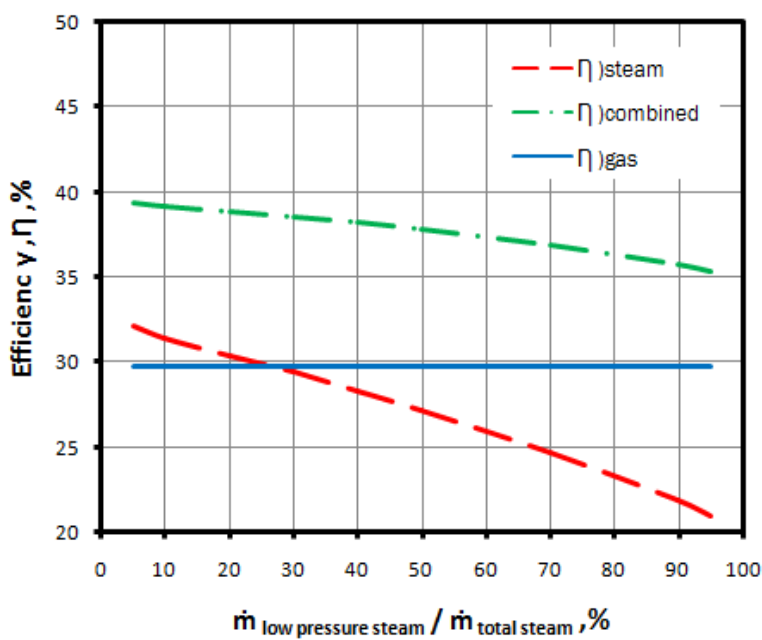

(b) 


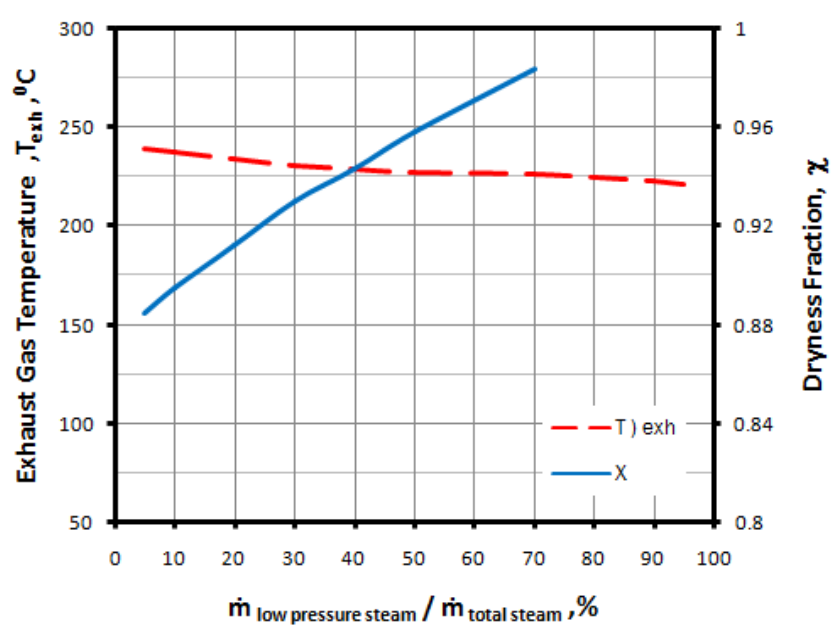

(C)

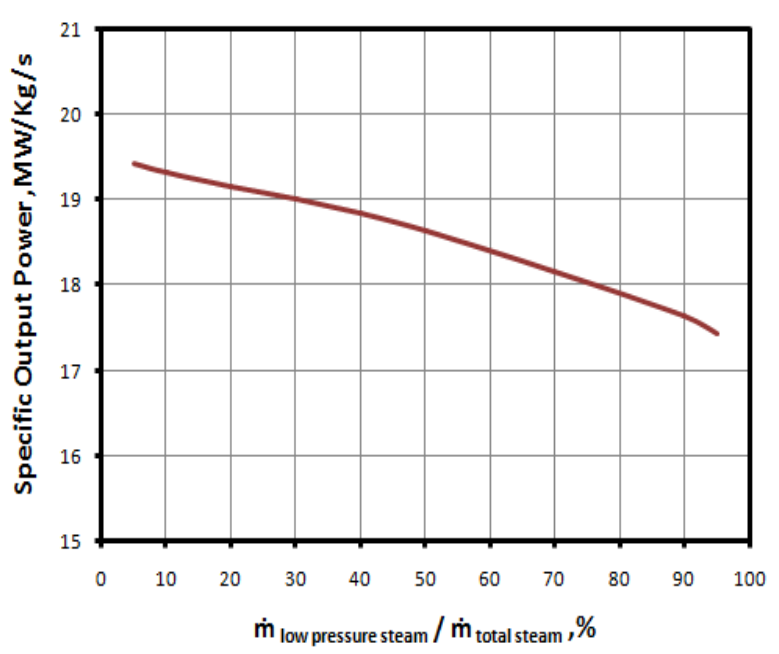

(d)

Fig.5 Effect of changing the mass flow rate fraction of the low pressure steam on the performance of the combined plant.

$$
\left(\mathrm{R}_{\mathrm{P}}=16.9, \mathrm{~T}_{\mathrm{air}}=293 \mathrm{~K}, \dot{m}_{\text {fuel }}=30 \mathrm{Kg} / \mathrm{s}\right)
$$

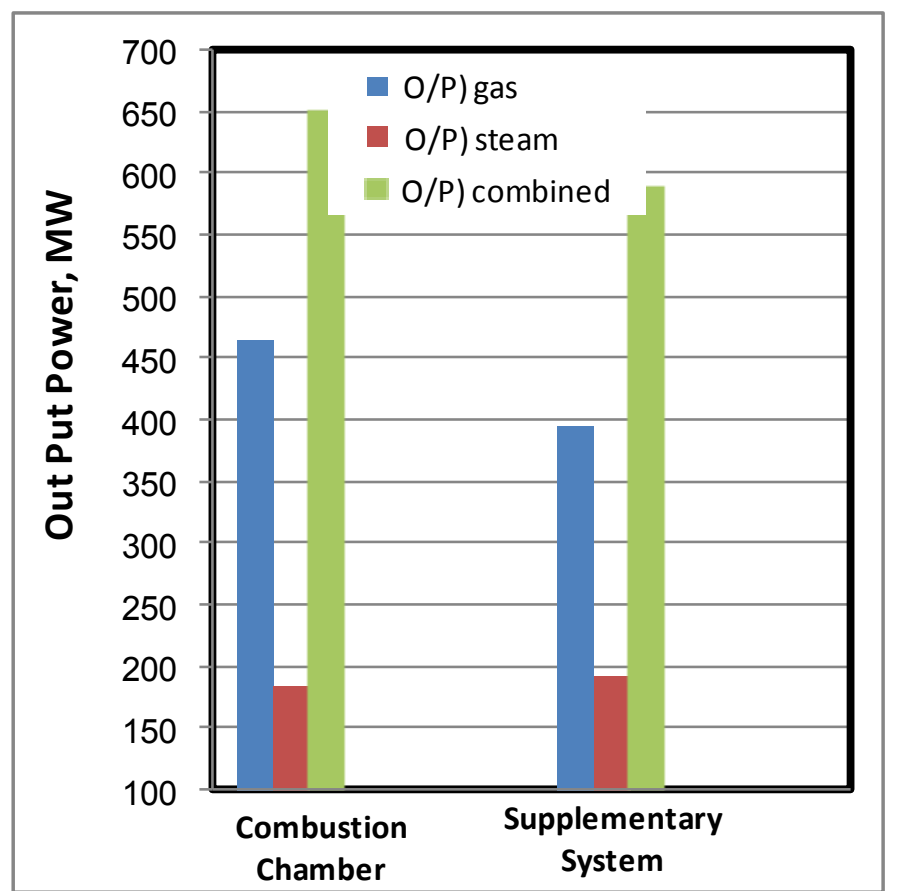

(a)

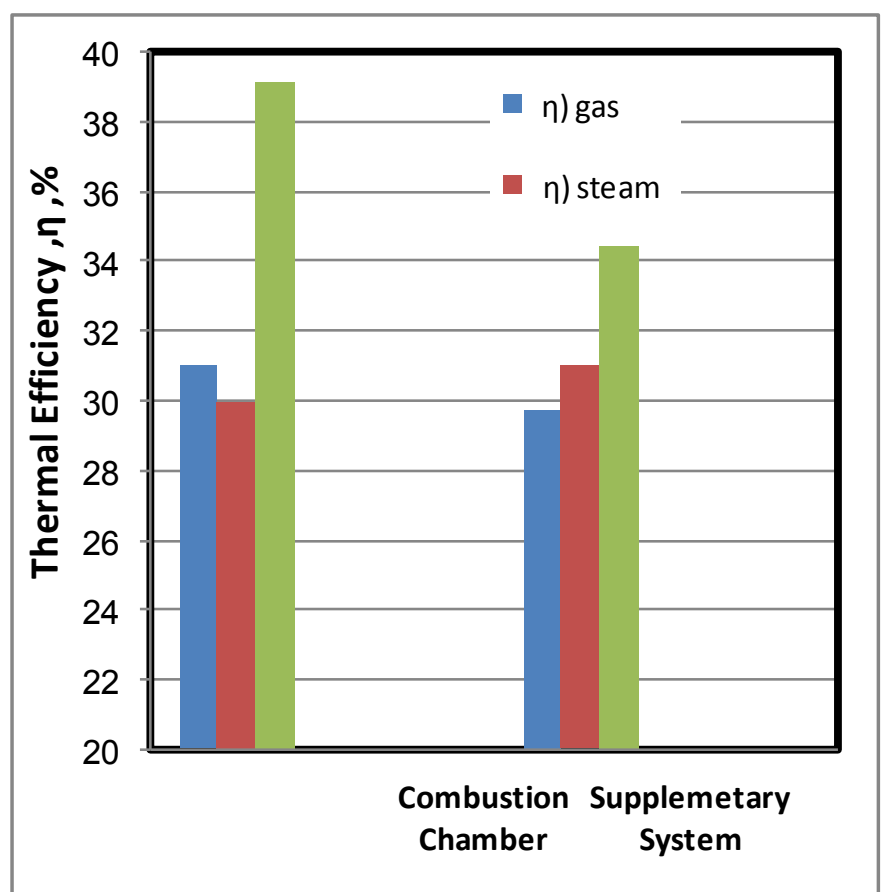

(b) 


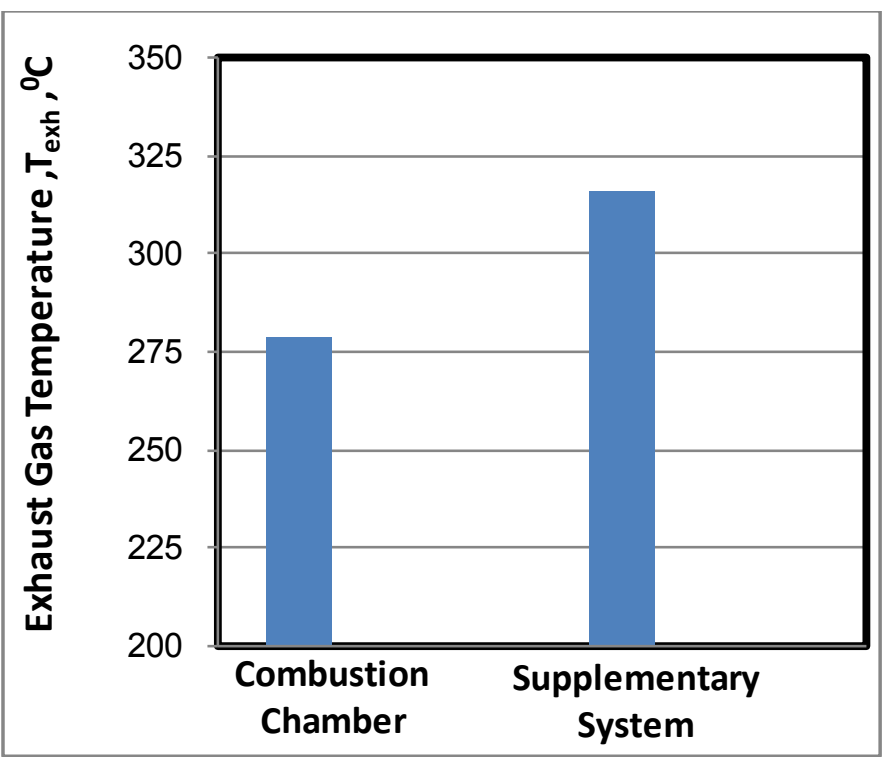

(c)

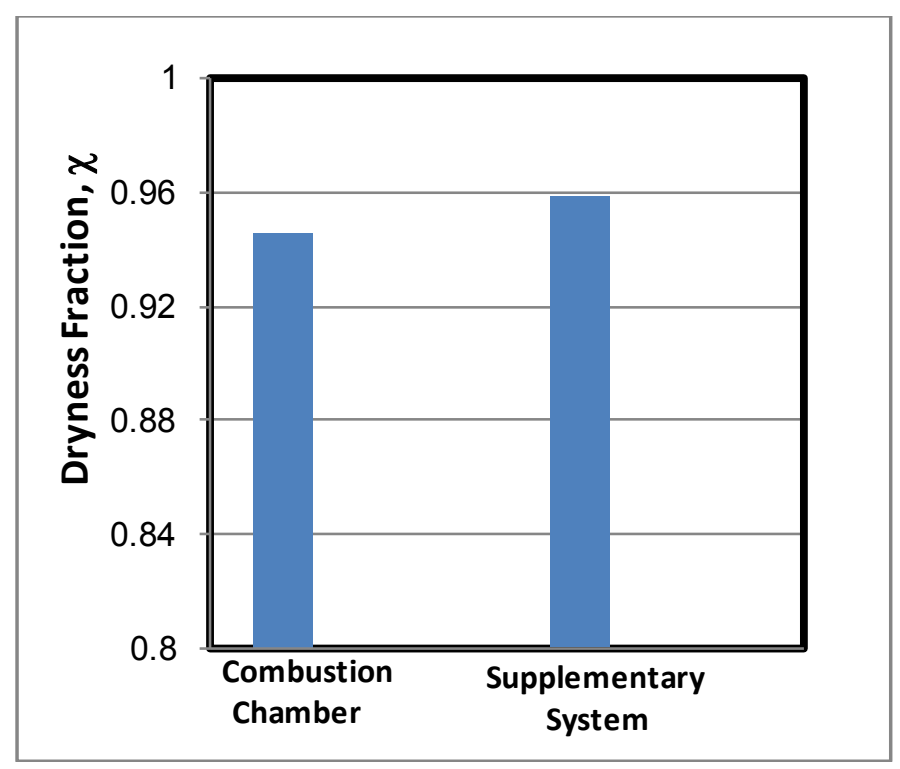

(d)

Fig.6 Comparison of Burning Extra Fuel in Combustion Chamber or Supplementary System. 